\title{
Effect of Prosopis Juliflora on the Soil Fertility in Usilampatti zone, Tamil Nadu
}

\author{
Sundaravel Balachandran, Stalindurai Kesavan, Arunpandi Pandi
}

\begin{abstract}
The invasion of Prosopis Juliflora in the tropical and sub-tropical ecosystems reached alarming condition because of their allelopathic nature and potential threat to the diversity. In this paper, the effect of Prosopis Juliflora on soil fertility in Usilampatti area is analysed. The concentration of macronutrients and micronutrients beneath and outside the Prosopis Juliflora canopy is studied and compared. The paper also explains the soil characteristics on the basis of the $\mathrm{pH}$ of the soil sample.
\end{abstract}

Keywords- Prosopis Juliflora, Invaded species, soil amelioration, biodiversity

\section{INTRODUCTION}

$\mathrm{A}_{\mathrm{t}}$ the onset of $19^{\text {th }}$ century, the demand for fuel wood kept on rising because $70 \%$ of the population relay on wood for cooking. To meet the increasing demand for fuel wood Prosopis Juliflora belongs to the central and South American plant species are introduced in the Indian subcontinent $[1,2]$. Although these kind of outlandish species have several economic benefits, they became a predator to the native species and alter the structure and function of the hosting ecosystem [3-4]. Recently Chandrasekaran et al reported the invaded Prosopis Juliflora community on nesting success of breeding wetland birds at Vettangudi Bird Sanctuary [5]. The study concluded that the Prosopis Juliflora poses threat to the birds by altering the birds assembling point [6], offering unsuitable location for breeding and increasing the nest predation [7]. Researchers are interested in studying the impact of Prosopis Juliflora in soil characteristics. El-Keblawy investigated the effects of Prosopis Juliflora on native plant communities and the quality of the soil. The study depicted that the soil beneath the canopy enriched with macronutrients like $\mathrm{N}, \mathrm{P}$ and $\mathrm{K}$. The $\mathrm{pH}$ of the soil also increased considerably [8]. Kaur et al reported the Prosopis Juliflora invasion in various parts of India and the species fixes nitrogen, soluble salts and exchangeable phosphorous along with high concentration of phenolic compounds [9]. Bhojvaid et al performed a long-term soil dynamics study in Prosopis Juliflora and explained the various phases of soil rejuvenation mechanism [10]. Vallejo et al reported that
Prosopis Juliflora trees are resource islands and established that Intensive Silvopastoral Systems (ISS) can be an alternate for conventional monocultures pastures [11]. Ruthven et al summarized the effect of Prosopis Juliflora in Biodiversity of the ecosystem. The species encouraged the growth of certain plants but retards growth of the forage plants which in turn brings an imbalance in biodiversity of the ecosystem and becomes a threat to crop cultivation and reduce the livestock feed [12].

Tamil Nadu is one among the many states which is having a semi-arid climate condition in India. The semi-arid climate doesn't support the plant growth and regeneration of species. About $10 \%$ of the land area is semi-arid in Tamil Nadu. In southern districts of Tamil Nadu the Prosopis Juliflora occupies the water reservoirs and farmlands thereby posing severe threats to the agricultural lands and water sheds. However there are not many reports pertaining to the effects of Prosopis Juliflora on soil quality, herbaceous vegetation, microbial community and avifauna are published. Madurai district have the semi-arid lands and climate conditions are little harsh. The Prosopis Juliflora species are predominantly distributed in the towns, villages of Madurai district and posing severe threat to the soil quality.

Hence, this paper reports the impact of Prosopis Juliflora species on soil nutrients of selected ecosystems beneath the canopy and outside the canopy. This article also illustrates the $\mathrm{pH}$ characteristics of the soil covered by Prosopis Juliflora canopy as well as the soil present in the open space.

\section{EXPERIMENTAL STUDIES}

In Madurai district, the areas around Usilampatti town are selected to study the effect of Prosopis Juliflora on soil characteristics. Usilampatti received on average annual rainfall of about $696.5 \mathrm{~mm}$ in the year 2018 [13]. In the study area different aged Prosopis Juliflora plants are located at the banks of the cultivable lands and well scattered as shown in the following figure 1 .

\footnotetext{
Revised Manuscript Received on December 09, 2019.

* Correspondence Author

Sundaravel Balachandran,Department of Chemistry, Kalasalingam Academy of Research and Education, Krishnankoil, India. Email: sundaravel.b@klu.ac.in

Stalindurai Kesavan*,Department of Chemistry, Kalasalingam Academy of Research and Education, Krishnankoil, India. Email: stalindurai8@gmail.com

Arunpandi Pandi, Department of Chemistry, Kalasalingam Academy of Research and Education, Krishnankoil, India.
} 


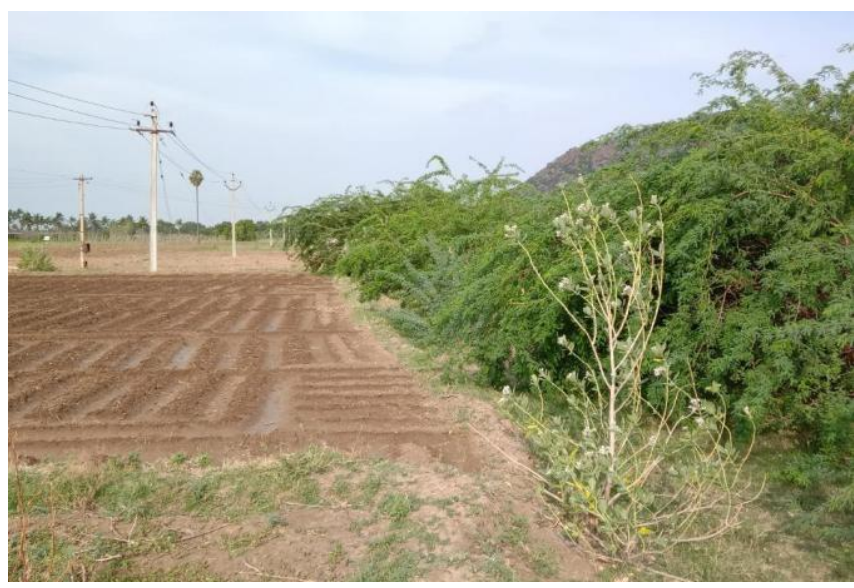

Figure 1: Prosopis Juliflora at the banks of cultivable lands - Usilampatti

\section{SOIL ANALYSIS}

The soil samples for nutrient content analysis are collected as follows. A hole of about $15 \mathrm{~cm}$ was made at a point located halfway between the major trunk and the edge of the canopy and soil sample was collected. This sample is called control sample and labelled as UCKS 1. Similarly, another sample also collected from the point $3 \mathrm{~m}$ away from the edge of the canopy. This sample is labelled as UKS 1 . Totally 5 set of samples are collected as mentioned above. Thus collected soil samples are submitted to the Tamilnadu Soil Analyzing Department - Virudhunagar Zonal Office and studied for amount of micro and macronutrients present in the sample using various chemical and soil analytical techniques. The results obtained are given in the following table 1 and 2 .

Table 1: Macro nutrient content analysis in the soil beneath and outside $P$. Juliflora canopy

\begin{tabular}{|l|l|l|l|}
\hline \multirow{2}{*}{$\begin{array}{l}\text { Sample } \\
\text { code }\end{array}$} & \multicolumn{3}{|c|}{$\begin{array}{c}\text { Macro nutrients } \\
\text { (mg kg }\end{array}$} \\
\cline { 2 - 4 } & $\mathbf{N}$ & \multicolumn{1}{|c|}{$\mathbf{P}$} & \multicolumn{1}{c|}{ K } \\
\hline UKS 1 & 61.6 & 28.6 & 50 \\
\hline UCKS 1 & 89.6 & 32.3 & 40.7 \\
\hline UKS 2 & 63.2 & 29.1 & 50.8 \\
\hline UCKS 2 & 90.2 & 32.3 & 40.9 \\
\hline UKS 3 & 59.8 & 27.3 & 52.1 \\
\hline UCKS 3 & 88.6 & 32.1 & 41.2 \\
\hline UKS 4 & 62.2 & 30.1 & 53.8 \\
\hline UCKS 4 & 90.1 & 33.8 & 42.5 \\
\hline UKS 5 & 60.5 & 29.7 & 52.1 \\
\hline UCKS 5 & 90.2 & 33.2 & 41.3 \\
\hline
\end{tabular}

Table 2: Micro nutrient content and $p H$ analysis in the soil beneath and outside $P$. Juliflora canopy

\begin{tabular}{|c|c|c|c|c|c|}
\hline \multirow[t]{2}{*}{$\begin{array}{l}\text { Sample } \\
\text { code }\end{array}$} & \multicolumn{4}{|c|}{$\begin{array}{l}\text { Micro nutrients } \\
\quad\left(\mathrm{mg} \mathrm{kg}^{-1}\right)\end{array}$} & \multirow[t]{2}{*}{ pH } \\
\hline & $\mathbf{F e}$ & Mn & $\mathbf{Z n}$ & $\mathbf{C u}$ & \\
\hline UKS 1 & 6 & 5.9 & 2.9 & 0.9 & 8.2 \\
\hline UCKS 1 & 4.1 & 4.9 & 0.01 & 0.8 & 7.3 \\
\hline UKS 2 & 6.2 & 5.9 & 3.1 & 0.96 & 8.4 \\
\hline UCKS 2 & 4.7 & 5.1 & 0.02 & 0.86 & 7 \\
\hline
\end{tabular}

\begin{tabular}{|l|l|l|l|l|l|} 
UKS 3 & 6 & 5.5 & 3.1 & 0.88 & 8.1 \\
\hline UCKS 3 & 3.8 & 4.1 & 0.01 & 0.7 & 6.9 \\
\hline UKS 4 & 6.2 & 6 & 3.2 & 1.2 & 8.6 \\
\hline UCKS 4 & 4.3 & 5.2 & 0.03 & 1 & 7.4 \\
\hline UKS 5 & 6.3 & 6.5 & 3.5 & 0.9 & 8.8 \\
\hline UCKS 5 & 5.1 & 5.8 & 0.02 & 0.78 & 7.2 \\
\hline
\end{tabular}

\section{RESULT AND DISCUSSION}

Being a xerophyte plant Prosopis Juliflora can withstand harsh climate conditions and has high economical values in the desert ecosystem [14-15]. The desert ecosystem doesn't have much flora and fauna and species richness. This ecosystem also has low level of underground water table. When a plant from such ecosystem is introduced to tropical ecosystem with a variety of species to avail the same economic benefits it may led to some undesirable change in the ecosystem. The Prosopis Juliflora is a leguminous plant and can help to fix the atmospheric nitrogen which is well shown in the soil analysis report. The soil samples collected beneath the canopy showed an increase in concentration of nitrogen. The soil collected beneath and outside the canopy did not show much variation in the phosphorous concentration. The Prosopis Juliflora species has some marked effect in the potassium concentration in soil samples. The samples collected under the branches of the Prosopis Juliflora showed lesser concentration of potassium because the potassium ions present in the soil is used by the plant to maintain the Na-K cycle. The slight decrease in the $\mathrm{pH}$ of the soil can also be correlated to the decrease of the potassium concentration.

The micronutrients like $\mathrm{Fe}, \mathrm{Zn}, \mathrm{Cu}$ and $\mathrm{Mn}$ are required for photosynthesis, DNA transcription and many more biological processes. These micronutrients are present in trace quantities in the soil. Since these nutrients are most essential for metabolic activities they are consumed by the plant species. Prosopis Juliflora to sustain the harsh climatic conditions it consumes the micronutrients present in the soil and it is well reflected in the soil analysis. The soil samples which are present in the shadow of Prosopis Juliflora showed a significant decrease in micronutrients concentration from the soil samples collected from the uncovered regions. Hence it is concluded that the Prosopis Juliflora increases nitrogen concentration and helps in amelioration of the degraded soil. In addition the plant also consumes the micronutrients thereby directly affect the other plant species in the ecosystem. Further it is reported that Prosopis Juliflora species have a tap root system which reduces the underground water level [16].

\section{CONCLUSION}

The soil samples were collected beneath outside the Prosopis Juliflora canopy. The nutrients content of the sample were tested and the findings were tabulated.

The concentration of macronutrients like nitrogen, phosphorous and potassium in the soil samples collected 
beneath the canopy (UCKS) were compared with the soil samples collected outside the canopy (UKS). It is concluded that concentration of nitrogen is higher in UCKS samples than UKS samples. This is due to the inherent nature of the leguminous plants [17]. The soil beneath the Prosopis Juliflora canopy has low concentration of micronutrients like iron, manganese, copper and zinc because of their consumption by the Prosopis Juliflora. From the study, it could be inferred that Prosopis Juliflora could be a harmful species to the biodiversity of the ecosystems and also it is possible threat to the underground water.

\section{ACKNOWLEDGMENT}

The authors sincerely thank the management of Kalasalingam Academy of Research and Education, Tamil Nadu, India for their constant encouragement and support and providing all the necessary facilities for carrying out this study.

\section{REFERENCES}

1. E.Mwangi and B. Swallow, Report, World Agroforestry Centre, Kenya, 2005, pp. 1-66.

2. $\quad$ N.M.Pasiecznik, P. Felker, P.J.C. Harris, L.N. Harsh and G. Cruz, "The Prosopisjuliflora - Prosopis pallida Complex: A Monograph”, 2001, Coventry, UK: HDRA.

3. S.Chandrasekaran and P.S. Swamy, "Biomass, litterfall and aboveground net primary productivity of herbaceous communities in varied ecosystems at Kodayar in the western ghats of Tamil Nadu", Agric. Ecosyst. Environ., vol. 88, 2002, pp. 61-71.

4. D.A.Wardle, R.D. Bardgett, R.M. Callaway and W.H. Van der Putten, Science, vol. 332, 2011, pp. 1273-1277.

5. S.Chandrasekaran,K.Sarswathy, S.Saravanan, N. Kamaladhasan, N ArunNagendran, "Impact of Prosopisjuliflora on nesting success of breeding wetland birds at Vettangudi Bird Sanctuary, South India", Current Science, vol. 106, 2014, pp. 676-678.

6. B.L.Beachy and G. R. Robinson,"Divergence in avian communities following woody plant invasions in a pine barrens ecosystem",Nat. Areas J., vol. 28, 2008, pp. 395-403.

7. J.F.Chace and J.J. Walsh,"Urban effects on native avifauna: A review. Landscape and Urban Planning, Landsc". Urban Plann., vol. 74, 2006, pp. 46-69.

8. A. El-Keblawy and A. Al-Rawai, "Impacts of the invasive exotic Prosopisjuliflora (Sw.) D.C.on the native flora and soils of the UAE", Plant Ecol., 2007,vol. 190, pp. 23-35.

9. R. Kaur, W.L. Gonzales, L.D. Llambi, P.J. Soriano, R.M. Callaway, M.E. Rout, T.J. "Gallaher and Inderjit, Community Impacts of Prosopisjuliflora Invasion: Biogeographic and Congeneric Comparisons", PLoS ONE, Vol. 7, 2012, pp. 1-13.

10. P.P. Bhojvaid and V.R. Timmer, "Soil dynamics in an age sequence of Prosopisjuliflora planted for sodic soil restoration in India", Forest Ecol.Manag., Vol. 106, 1998, pp. 181-193.

11. V.E. Vallejo, Z. Arbeli, W. Teran, N. Lorenz, R.P. Dick, F. Roldan, "Effect of land management and Prosopisjuliflora (Sw.) DC trees on soil microbial community and enzymatic activities in intensive silvopastoral systems of Colombia, Agric". Ecosyst. Environ., Vol. 150, 2012, pp. 139-148.

12. D.C. Ruthven, "Herbaceous vegetation diversity and abundance beneath honey mesquite (Prosopisglandulosa) in the South Texas plains", Texas Journal of Science, vol. 53, 2001, pp. 171-186.

13. C.Nivetha and V.Janahiraman, "Rainfall analysis and suggested cropping system forUsilampatti Taluk of Madurai district, Tamil Nadu", J.Pharmacogn.Phytochem., vol. 7, 2018, pp. 157-160

14. P.N. Daveand J. Bhandari, "Prosopisjulifera": A review,Int. J. Chem. Stud., vol. 1, 2013, pp. 2321-4902.

15. K.J. Walterand and K.V. Armstrong, "Benefits, threats and potential of Prosopis in South India,For trees livelihoods", vol. 23, 2014, pp. 232-247.

16. R. ThiruniraiSelvan. K.T. Parthiban and B. Palanikumaran, "Prosopisjuliflora - A Myth and Reality to the Current Development Scenario in Tamil Nadu", Int. J. Pure App. Biosci., vol. 6, 2018, pp. 1088-1092
17. O.Diagneand D. D. Baker, "Quantification of symbiotic $\mathrm{N}$ fixation by Prosopisjuliflora (Swartz) DC using ${ }^{15}$ Nisotope dilution methodology". Soil Biol. Biochem., vol. 26, 1994, pp. 1709-1710

\section{AUTHORS PROFILE}

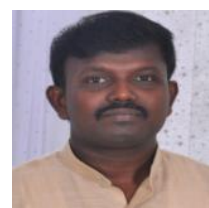

Sundaravel Balachandran received his doctorate in Chemistry from Anna University, Chennai, Tamil Nadu-India. His major area of research interest is heterogeneous catalysis. $\mathrm{He}$ is having about 14 publications to his credit.

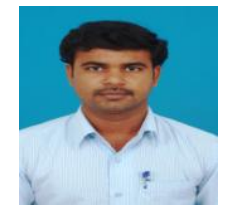

Stalindurai Kesavan received his doctorate in Chemistry from Kalasalingam Academy of Research and Education, Krishnankoil, Tamil Nadu-India. His major area of research interest is synthetic organic chemistry. $\mathrm{He}$ is having about 11 publications to his credit.

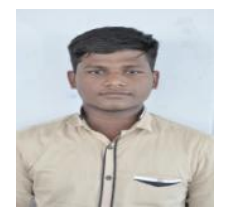

Arunpandi Pandi pursuing B.Sc. Chemistry in Kalasalingam Academy of Research and Education, Krishnankoil, Tamil Nadu-India. 